\title{
Effects of the pleural drain site on the pulmonary function after coronary artery bypass grafting
}

\author{
Efeitos do local de inserção do dreno pleural na função pulmonar no pós-operatório de cirurgia de \\ revascularização do miocárdio
}

Solange GUIZILINI, Walter J. GOMES, Sonia M. FARESIN, Antonio Carlos C. CARVALHO, Jaime I. JARAMILLO, Francisco A. ALVES, Roberto CATANI, Enio BUFFOLO

RBCCV 44205-669

\section{Abstract}

Objective: To analyze pulmonary functional changes and pain in patients undergoing off-pump coronary artery bypass grafting utilizing a left internal thoracic artery graft, comparing pleural drain insertion through the intercostal space and the subxyphoid approach.

Methods: Twenty-eight patients (mean age $57.4 \pm 8.4$ years) were divided into two groups, according to the pleural drain site. Group LI $(n=15)$ had the pleural drain inserted through the sixth left intercostal space at the mid-axillary line and in the MI group $(n=13)$ the drain was placed through the subxyphoid region. All the patients underwent pre- and postoperative evaluations of pulmonary function tests as well as arterial blood gas analysis. Forced vital capacity (FVC) and forced expiratory volume over one second $\left(F E V_{1}\right)$ were recorded in the preoperative period, and on the first, third and fifth postoperative days. The pain sensation was evaluated using a standard score from 0 to 10 .
Results: In both groups, falls in the FVC and $F E V_{1}$ were noted, up to the fifth postoperative day $(P<\mathbf{0 . 0 0 1})$. However the decrease was higher in the LI group, when compared to the MI group $(\mathbf{p}<0.05)$. Also arterial blood gas analysis showed a decline of the partial oxygen pressure in both groups on the first postoperative day, but more significantly in the LI group $(p=0.021)$. The pain sensation was higher in the LI group $(\mathrm{p}=\mathbf{0 . 0 0 2})$.

Conclusion: Off-pump coronary artery bypass grafting using the left internal thoracic artery, disregarding the pleural drain site, leads to a significant decrease of postoperative pulmonary function. However, the subxyphoid technique of drain insertion has shown a better preservation of the lung function when compared to the intercostal drain site.

Descriptors: Coronary artery bypass surgery. Pleural drain. Pulmonary function.

Work performed in the Pirajussara and São Paulo Hospitals

Cardiovascular Surgery and Cardiology Departments, Escola Paulista

de Medicina - Federal University of São Paulo.

Rua Botucatu 740 - 04023-900 São Paulo - SP

This article is part of the master's dissertation of physiotherapist Solange Guizilini (Tutor: Prof. Dr. Walter J. Gomes).

Correspondence address: Rua Pedro Inácio de Araújo, 202 Ap. 13 A -

Vila São Francisco 05386-330 - São Paulo Phone: (011) 37635387 cellular: (011) 81419978

E-mail: sguizilini@uol.com.br 
Objetivo: Analisar a alteração da função pulmonar e dor em pacientes submetidos à cirurgia de revascularização do miocárdio (RM) com enxerto da artéria torácica interna esquerda (ATIE), sem circulação extracorpórea (CEC), comparando a inserção do dreno pleural nas regiões intercostal e subxifóide.

Método: Vinte e oito pacientes (média de idade 57,4 $\pm \mathbf{8 , 4}$ anos) foram alocados em dois grupos, de acordo com a posição do dreno pleural. Grupo IL $(n=15)$ com inserção do dreno no sexto espaço intercostal esquerdo na linha axilar média; e grupo IM $(n=13)$ inserção do dreno na região subxifóide. Todos os pacientes foram submetidos à avaliação da função pulmonar. Registros espirométricos da capacidade vital forçada (CVF) e do volume expiratório forçado no primeiro segundo $\left(\mathrm{VEF}_{1}\right)$ foram obtidos no pré, primeiro, terceiro e quinto dia dias pós-operatório (PO) e a gasometria arterial em ar ambiente no pré e primeiro dia de pós-operatório. A sensação de dor foi quantificada por um escore padrão ( 0 a 10) no primeiro dia de pós-operatório.

\section{INTRODUCTION}

Coronary artery bypass grafting $(\mathrm{CABG})$ surgery utilizing left internal thoracic artery (LITA) grafts has proved to provide remission of the anginal symptoms and contribute to extend and improve the quality of life of patients suffering from coronary diseases [1]. However, in the majority of the procedures, the attainment of the LITA pedicle involves opening the left pleural cavity, which subsequently requires draining. This pleurotomy, associated with the presence of a pleural drain, contributes to the discomfort of the patient, functioning as an additional factor in deteriorating the respiratory mechanics $[2,3]$.

The insertion of a intercostal pleural drain causes additional injury to the thorax, as it becomes necessary to perforate intercostal muscles and the parietal pleura, interfering in the respiratory movements $[4,5]$. Consequently, the location of the pleural drain might have an influence of the discomfort suffered by the patient and on the degree of alterations of the pulmonary function.

In this work the effects of the pleural drain insertion site on the pulmonary function and pain were studied, comparing the intercostal with the subxiphoid insertion sites in the postoperative period of patients submitted to off-pump CABG surgery.

\section{METHOD}

This work was performed in the Pirajussara and São Paulo Hospitals, both belonging to the Federal University of São Paulo. The study was approved by the Ethics Committee
Resultados: Em ambos os grupos houve queda significativa

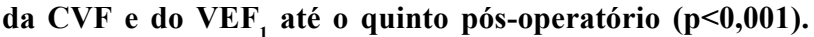
Quando comparados, a diferença entre os grupos se manteve significativa, com maior queda dos valores de CVF e VEF no grupo IL $(\mathbf{p}<\mathbf{0 , 0 5})$. A pressão parcial de oxigênio arterial apresentou queda significativa no primeiro dia de pósoperatório em ambos os grupos, porém com maior decréscimo no grupo IL $(p=0,021)$. A dor referida foi maior no grupo IL $(\mathbf{p}=\mathbf{0 , 0 0 2})$.

Conclusão: A cirurgia de RM sem CEC, utilizando a ATIE com pleurotomia esquerda, independente da posição do dreno pleural causa dor e queda significativa na função pulmonar no PO. Porém, a inserção do dreno pleural na região subxifóide demonstrou menor dor subjetiva com melhor preservação da função pulmonar quando comparada à inserção intercostal.

Descritores: Revascularização miocárdica. Drenagem pleural. Função pulmonar.

for Clinical Research and written consent forms were signed by participating patients in the study. A total of 28 patients participated with ages ranging from 46 to 74 years old and a mean age of $57.4 \pm 8.4$ years. Five $(17.8 \%)$ were female and $23(82.14 \%)$ male. All were suffering from coronary insufficiency evidenced by coronary cineangiography, left ventricle ejection fraction greater than $50 \%$ and the absence of acute or chronic pulmonary disease and were submitted to elective off-pump CABG using LITA grafts and left pleurotomy. The patients were grouped depending on the location of their pleural drain. In the LI Group or lateral insertion $(n=15)$, the drain was placed at the intersection of the sixth left intercostal space with the medial axially line and in the MI Group or medial insertion $(\mathrm{n}=13)$, the drain was placed in the subxiphoid region (Figure 1).

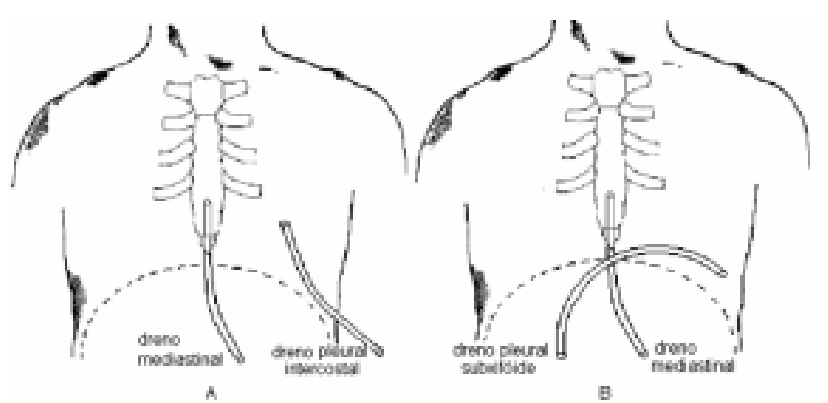

Fig. 1 - Demonstration of the site of the pleural drains. $A=$ pleural drain in the left intercostal region (lateral) and $\mathrm{B}=$ pleural drain in the subxiphoid region (medial). 
Table 1. Clinical and demographic characteristics of the Lateral insertion and Medial Insertion groups in respect to the age, gender, weight, height, body mass index, risk factors, preoperative pulmonary function and inter-operative data

\begin{tabular}{|c|c|c|c|c|}
\hline Variables & $\begin{array}{l}\text { Total } \\
\mathrm{n}=28\end{array}$ & $\begin{array}{l}\text { Group LI } \\
\mathrm{n}=15\end{array}$ & $\begin{array}{l}\text { Group MI } \\
\mathrm{n}=13\end{array}$ & $\mathrm{P}$ \\
\hline Age (years)* & $57.49 \pm 8.40$ & $57.53 \pm 10.29$ & $57.46 \pm 5.94$ & 0.66 \\
\hline \multicolumn{5}{|l|}{ Gender (n.\%) } \\
\hline Male & $23(82.14 \%)$ & $14(93.30 \%)$ & $09(69.20 \%)$ & \multirow[t]{2}{*}{0.15} \\
\hline Female & $05(17.85 \%)$ & $01(6.70 \%)$ & $04(30.80 \%)$ & \\
\hline Weight $(\mathrm{Kg})^{*}$ & $74.03 \pm 12.61$ & $72.13 \pm 12.69$ & $76.23 \pm 12.67$ & 0.25 \\
\hline Height $(\mathrm{cm}) *$ & $166.00 \pm 7.63$ & $166.13 \pm 6.36$ & $165.85 \pm 9.15$ & 0.87 \\
\hline BMI $\left(\mathrm{kg} / \mathrm{m}^{2}\right) *$ & $26.75 \pm 3.06$ & $26.12 \pm 3.08$ & $27.59 \pm 2.70$ & 0.12 \\
\hline \multicolumn{5}{|l|}{ Risk factors (n.\%) } \\
\hline Arterial hypertension & $26(92.85 \%)$ & $13(86.70 \%)$ & $13(100 \%)$ & 0.48 \\
\hline Diabetes mellitus & $13(46.42 \%)$ & $08(53.30 \%)$ & $05(38.50 \%)$ & 0.47 \\
\hline Dyslipidemia & $07(25.00 \%)$ & $04(26.70 \%)$ & $03(23.10 \%)$ & 1 \\
\hline Smoker current & $06(21.42 \%)$ & $04(26.70 \%)$ & $02(15.10 \%)$ & 0.65 \\
\hline Years/packets (average) & 54 & 24 & 30 & 0.62 \\
\hline Obesity & $04(14.30 \%)$ & $02(13.30 \%)$ & $02(15.40 \%)$ & 1 \\
\hline \multicolumn{5}{|l|}{ Pulmonary function } \\
\hline $\operatorname{VFC}(\mathrm{L}) *$ & $3.58 \pm 0.92$ & $3.69 \pm 0.68$ & $3.46 \pm 1.16$ & 0.61 \\
\hline$\%$ pred* & $99.34 \pm 0.15$ & $102.20 \pm 16.64$ & $96.05 \pm 13.72$ & 0.50 \\
\hline $\mathrm{FEV}_{1}(\mathrm{~L}) *$ & $2.88 \pm 0.73$ & $2.86 \pm 0.47$ & $2.90 \pm 0.97$ & 0.94 \\
\hline$\%$ of pred $*$ & $99.02 \pm 0.14$ & $98.89 \pm 14.40$ & $99.16 \pm 15.81$ & 0.90 \\
\hline $\mathrm{PaO}_{2}(\mathrm{mmHg}) *$ & $75.60 \pm 6.80$ & $74.40 \pm 6.85$ & $77.00 \pm 6.75$ & 0.36 \\
\hline $\mathrm{PaCO}_{2}(\mathrm{mmHg}) *$ & $37.96 \pm 3.77$ & $38.27 \pm 3.65$ & $37.62 \pm 4.03$ & 0.69 \\
\hline Surgery time (min)* & $308.21 \pm 20.33$ & $309.30 \pm 19.35$ & $306.90 \pm 22.13$ & 0.74 \\
\hline OTI time (hours)* & $10.25 \pm 1.10$ & $10.47 \pm 1.25$ & $10.00 \pm 0.91$ & 0.32 \\
\hline
\end{tabular}

Abbreviations: BMI - body mass index; FVC - Forced vital capacity; FEV1 - Forced expiratory volume in the first second; Ant - Anticipated; $\mathrm{PaO} 2$ - Partial arterial oxygen pressure; $\mathrm{PaCO} 2$ - Partial arterial carbon dioxide pressure; OTI - Orotracheal intubation.

* Mean values and standard deviation

The clinical and demographic characteristics of the LI and MI groups are presented in Table 1.

\section{Preoperative}

The history and clinical examination data were recorded on report cards detailing diagnoses, risk factors for coronary disease (systemic arterial hypertension, diabetes mellitus, dyslipidemia and smoking) and associated diseases. Also the nutritional state was evaluated, as was the pulmonary function by spirometry and arterial gasometry.

The nutritional state was determined by analysis of the body mass index (BMI) calculated as a ration of the weight/ height ${ }^{2}$. For patients up to 60 years old, the classification recommended by the World Health Organization [6] was employed. Thus a BMI less than $18.5 \mathrm{~kg} / \mathrm{m}^{2}$ refers to dystrophia or malnutrition, between 18.5 and $24.9 \mathrm{~kg} / \mathrm{m}^{2}$ to eutrophic individuals, between 24.9 to $29.9 \mathrm{~kg} / \mathrm{m}^{2}$ to overweight individuals and greater than $29.9 \mathrm{~kg} / \mathrm{m}^{2}$ to obese people. For over 60 -year-olds the classification of LIPSCHITZ [7] was utilized where less than $22 \mathrm{~kg} / \mathrm{m}^{2}$ classified malnourished individuals, 22 to $27 \mathrm{~kg} / \mathrm{m}^{2}$ eutrophic people and greater than $27 \mathrm{~kg} / \mathrm{m}^{2}$ obese. The spirometry evaluation constituted in the determination of the forced vital capacity value (FVC) and the forced expiratory volume over the first second $\left(\mathrm{FEV}_{\mathrm{l}}\right)$ according with the standards of the American Thoracic Society (ATS)[8].

Recordings of the FVC and FEV, were obtained in the preoperative period and on the $1^{\text {st }}, 3^{\text {rd }}$ and $5^{\text {th }}$ days in the postoperative period using a portable Spirobank G spirometer from Medgraph Ltda. The partial oxygen pressure in the arterial blood $\left(\mathrm{PaO}_{2}\right)$ was determined in the preoperative period and on the $1^{\text {st }}$ postoperative day in the environmental air, on both occasions before performing the spirometry.

All the patients were submitted to simple posterioranterior and profile chest radiographs. At the end of the preoperative evaluation, the patients received guidance about the surgery, the immediate postoperative period and the importance of the necessity of early breathing and walking exercises.

\section{Intraoperative}

The off-pump CABG was performed by median 
sternotomy using LITA grafts and left pleurotomy, complemented with additional grafts of the saphenous vein. Before the thorax was closed, the surgeons chose the site for the insertion of the pleural drain either at the intersection of the $6^{\text {th }}$ left intercostal space with the medial axially line or in the subxiphoid region. The end of the subxiphoid drain was positioned in the left costophrenic sinus.

A PVC tubular pleural drain was utilized in both groups, with that of the subxiphoid region in a $1 / 4$ inch curve and the intercostal straight. In all patients, a substernal tubular drain was also used placed in the mediastinum and the outlet located in the subxiphoid region.

\section{Postoperative}

The two groups were re-evaluated in relation to the pulmonary function on the $1^{\text {st }} 3^{\text {rd }}$ and $5^{\text {th }}$ postoperative days.

On the first postoperative day the subjective sensation of pain was measured using a modified standard score from 0 to 10 , where 0 indicated the absence of pain and 10 the presence of unsupportable pain [9]. This evaluation was initially effectuated at rest before performing spirometry.

All the patients performed daily simple chest radiograms, in the anteroposterior position to verify the presence of residual pleural collections. They were also submitted to daily physiotherapy sessions until release from hospital. The same professional always performed the evaluations, both in the preoperative and postoperative periods.

\section{Statistical analysis}

To test that the samples were homogenous, the Fisher exact test and the Mann-Whitney test were applied. The parameters of pulmonary function were analyzed using nonparametric tests: the Friedman test was used to compare trends over the time in each group; the Wilcoxon test was used to compare intra-group values (two-by-two) and the Mann-Whitney test compared the two groups. For all the statistical tests, a level of significance of $5 \%$ was adopted.

\section{RESULTS}

The groups did not present with significant differences in relation to the age, gender, body mass index, risk factors of coronary disease, preoperative pulmonary function, operative time or time of orotracheal intubation (Table 1).

In relation to pulmonary function, in both groups there was a significant drop of the $\mathrm{FVC}$ up to the $5^{\text {th }}$ postoperative day ( $p$-value $<0.001$ ). When comparing the two groups the difference remains significant, always with the greatest drop in the LI group.

The FVC percentage on the $1^{\text {st }}$ postoperative day in relation to the preoperative values in the LI and MI groups were $33.36 \pm 8.34 \%$ and $50.09 \pm 14.35 \%$, respectively, demonstrating a reduction of $66.64 \%$ of the FVC in the LI group. This drop was considerably greater when compared to a drop of $49.1 \%$ in the MI group (p-value 0.001 ).

On the $3^{\text {rd }}$ postoperative day the percentage drop of the $\mathrm{FVC}$ in the LI and MI groups were $45.42 \pm 7.06 \%$ and $67.00 \pm$ $15.88 \%$ respectively, giving a drop of $57.58 \%$ of the $\mathrm{FVC}$ in the LI group and a smaller drop of $33 \%$ in the MI group (pvalue $<0.001$ ).

The percentage drop on the $5^{\text {th }}$ postoperative day in the $\mathrm{LI}$ and MI groups were $55.13 \pm 8.30 \%$ and $78.22 \pm 11.90 \%$ respectively, giving a significant difference with a reduction of $44.87 \%$ in the LI group and $21 \%$ in the MI group (p-value $<0.001$ ) (Figure 2)

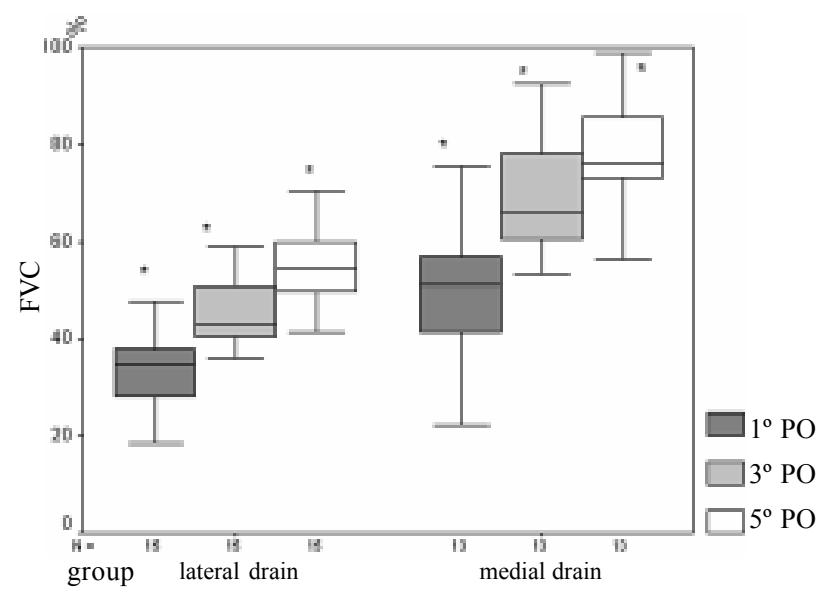

Fig. 2 - Distribution of the alterations in FVC as percentages on the $1^{\text {st }}, 3^{\text {rd }}$ and $5^{\text {th }}$ postoperative days in relation to the preoperative values. Comparing the groups with the insertion of the drain in the lateral and medial regions, considering the preoperative value as $100 \%$. $*$ p-value $<0.05$

In relation to the $\mathrm{FEV}_{1}$, there was also a significant drop in both groups up to the $5^{\text {th }}$ postoperative day (p-value $<$ 0.001 ). When the two groups were compared, the greatest loss was always seen in the LI group.

The FEV ${ }_{1}$ percentage on the $1^{\text {st }}$ postoperative day in relation to the preoperative values in the LI and MI groups were $35.70 \pm 8.66 \%$ and $50.44 \pm 13.18 \%$ respectively demonstrating a reduction of $64.30 \%$ in the LI group and $49.56 \%$ in the MI group ( $\mathrm{p}$-value $=0.003$ ).

On the third postoperative day the percentage $\mathrm{FEV}_{1}$ drops in the LI and MI groups were $48.04 \pm 7.22 \%$ and 67.09 $\pm 15.12 \%$ respectively showing a reduction of $51.96 \%$ in the LI group and $32.91 \%$ in the MI group (p-value $<0.001$ ).

The $\mathrm{FEV}_{1}$ percentages on the $5^{\text {th }}$ postoperative day in the LI and MI groups were $58.80 \pm 8.51 \%$ and $79.56 \pm 11.52 \%$ respectively, demonstrating that the difference remained 
significant with a loss of $41.2 \%$ in the LI group and $21 \%$ in the MI group (p-value $<0.001$ ) (Figure 3 ).

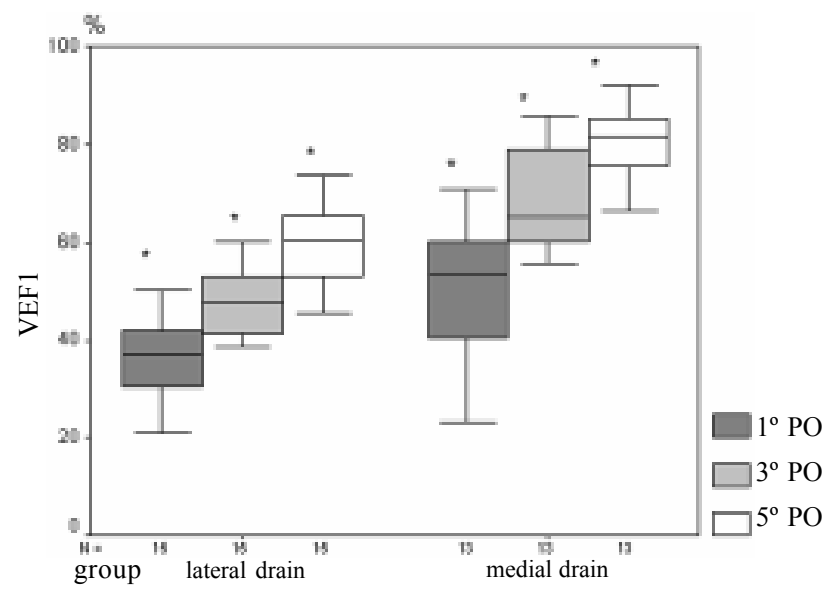

Fig. 3 - Distribution of the VEF alterations as percentages of the preoperative values on the $1^{\text {st }}, 3^{\text {rd }}$ and $5^{\text {th }}$ postoperative days. Comparing the groups with the insertion of the drain in the lateral and medial regions, considering the preoperative value as $100 \%$. p-value $<0.05$

With respect to the $\mathrm{PaO}_{2}$, there was a significant drop in the first day for both groups ( $\mathrm{p}$-value $=0.001$ ), but the values in the LI group were lower than those of the MI group. The percentage of $\mathrm{PaO}_{2}$ on the $1^{\text {st }}$ postoperative day in relation to the preoperative values in the LI and MI groups were $76.54 \pm 9.11 \%$ and $84.90 \pm 7.79 \%$ respectively, giving a reduction of $23.46 \%$ in the LI group and $15.1 \%$ in the MI group $(\mathrm{p}$-value $=0.021)($ Figure 4$)$.

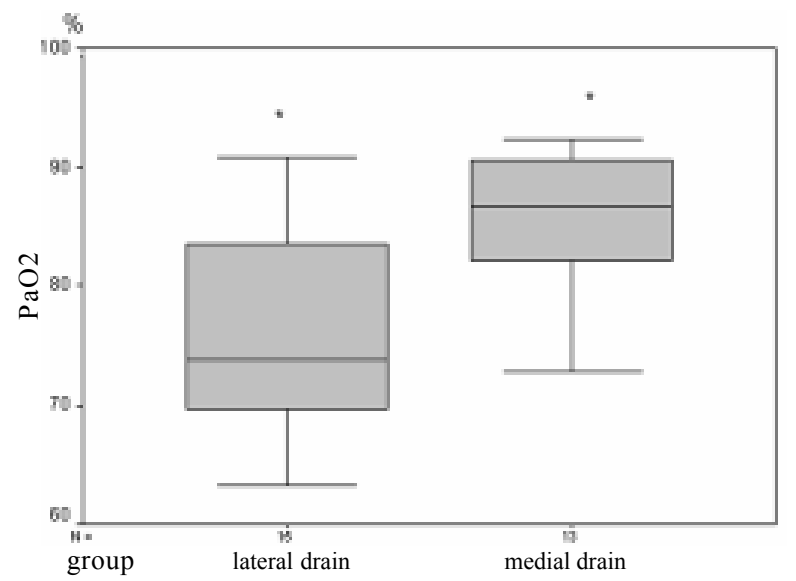

Fig. 4 - Distribution of the partial arterial oxygen pressures $\left(\mathrm{PaO}_{2}\right)$ as a percentage on the $1^{\text {st }}$ postoperative day in relation to the preoperative values. Comparing the groups with the insertion of the drain in the lateral and medial regions, considering the preoperative value as $100 \%$. * p-value $<0.05$
All the patients presented with pain on the first postoperative day, but the intensity of pain in the LI group was greater, with a statistically significant difference. The distributions of the pain score were distinct, with a mean of $7.2 \pm 1.52$ for the LI group and $5.00 \pm 1.58$ for the MI group $(p$-value $=0.002)($ Figure 5$)$.

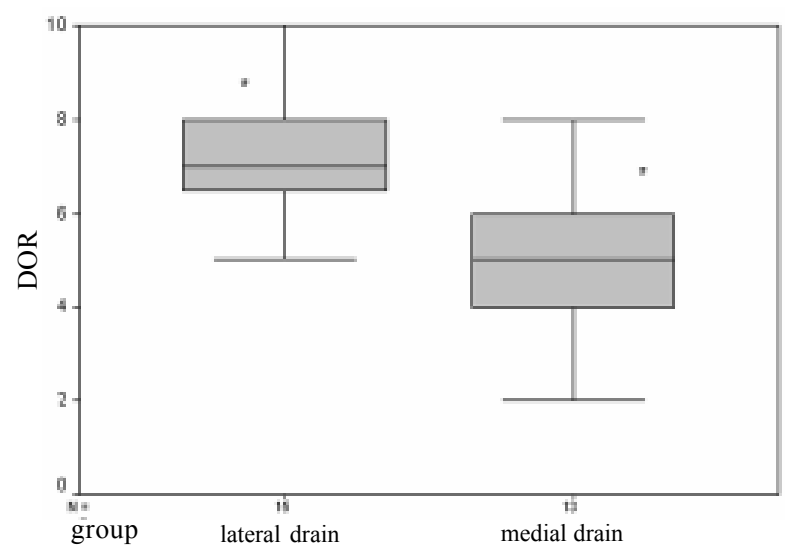

Fig. 5 - Distribution of the average pain score on the $1^{\text {st }}$ postoperative day. Comparing the groups with the insertion of the drain in the lateral and medial regions. * p-value $<0.05$

The serial postoperative radiographs, in both groups, did not demonstrate the presence of pleural collections. All the drains were removed on the $2^{\text {nd }}$ postoperative day.

\section{DISCUSSION}

Confirming existing findings, this study demonstrated that there is deterioration in the pulmonary function in the postoperative period of CABG surgery with the use of LITA grafts and left pleurotomy [3]. The reduction in the pulmonary function is the result of the combination of several factors, including the general anesthesia, median sternotomy, cardiopulmonary bypass (CPB) [2] and diaphragmatic dysfunction [10]. As well as these, there is the additional factor of the pleural drainage required because of the use of LITA grafts with pleurotomy [3,11]. Previous studies demonstrated that, independent of the surgical technique utilized, CPB causes pulmonary injury and retards recovery of the respiratory function [12]. This highlights the importance of this study, investigating patients submitted to off-pump CABG grafting, comparing the effects of the location of the pleural drain installation site, either intercostal or subxiphoid, on the pulmonary function, where the harmful effects and related variables of $\mathrm{CPB}$ were eliminated.

In respect to the pulmonary function, this study demonstrated that even without $\mathrm{CPB}$, there was a significant drop in the pulmonary function up to the $5^{\text {th }}$ postoperative 
day in both groups, with deterioration of the values of FVC and $\mathrm{FEV}_{1}$. However, the MI group presented with a lesser drop of these parameters, when compared to the LI group. A similar result was found by HAGL et al. [13], in a study of patients submitted to CABG surgery using CPB with the use of LITA grafts, where the drains were inserted in the intercostal region or the subxiphoid region.

In this study, although the differences remained significant when comparing the values on the $5^{\text {th }}$ postoperative day, the MI group presented a mean FVC of $78.22 \%$ in relation to the preoperative period, but the upper limit reached $100 \%$, while in the LI group, the upper limit was only $70 \%$. We observed that the FVC did not completely return to normal on the $5^{\text {th }}$ postoperative day, but the values of the MI group, when compared to the LI group, were closer to the preoperative values.

According to OIKKONEN et al. [14], a reduction of the FVC may determine a drop in the expiratory flow peak (EFP), which immediately after the surgery was also reduced. This drop has clinical importance as it reflects the capacity to cough, debility on coughing and the movement of secretions. Early closure and obstruction of the small airways predispose the patient to micro-atelectasis and consequently the reduction of the $\mathrm{PaO}_{2}$ in the arterial blood [15].

In this study, although the EFP was not measured, the reduction in the FVC could have provoked its drop, mainly in the intercostal group, where the reduction of the FVC was greater, predisposing the patient to higher risks of developing pulmonary complications. Gas exchange was seen to be altered in this study. YAMAGISHI et al. [16] demonstrated that arterial hypoxemia occurs normally after CABG surgery and persists for several weeks. Some authors have demonstrated there is a greater drop in the $\mathrm{PaO}_{2}$ with the use of LITA grafts subsequent to the effect of pleurotomy with pleural drains [17]. They also commented that recovery is slower due to the presence of the drain in the thorax, that is, to the additional injury imposed of the thoracic wall $[11,18]$.

In the same study, even without the use of CPB, we observed a significant drop in the $\mathrm{PaO}_{2}$ on the $1^{\text {st }}$ postoperative day in both the groups. But the LI group presented with a reduction of $23.46 \%$ whilst the MI group suffered a drop of only $15.10 \%$. Thus, the position of the pleural drain seems to have been an important factor in the deterioration of the oxygenation pressure after the surgery.

In the study by Hagl et al. There was no significant difference between the groups studied, probably due to the individual supplements of oxygen given to the patients. However, they demonstrated the necessity of supplementary oxygen was less in patients with the drain in the subxiphoid region.

Several mechanisms may contribute to the appearance of hypoxemia: alveolar hypoventilation, alterations in the ventilation-perfusion ratio, reduction of diffusion and shunt, with this latter being the most common [17,18]. One of the proposed mechanisms for the appearance of a shunt is the reduction of the FVC [17]. According to ALI et al. [19], the reduction of the FVC causes a drop in the $\mathrm{PaO}_{2}$ by two mechanisms: first by the formation micro-atelectasis or peripheral alveolar collapse and second by the early closure of the small airways. With the reduced FVC, the pulmonary volume becomes very similar to the volume of closure during ventilation at rest, leading some alveolar segments to become permanently closed [20]. These facts might justify, in our study, the greater drop in oxygenation in the intercostal group, due to the greater reduction in FVC.

In respect to pain and the position of the pleural drain, this study demonstrated that patients with the subxiphoid location reported less pain than those with insertion in the intercostal space. Similar results were described by RIEBMAN et al. [21], who described the technique of insertion of the pleural drain in the subxiphoid region, aiming at reducing the postoperative discomfort caused by friction of the drain in the intercostal space. Hagl et al. [13] also showed that the pain in patients with subxiphoid implantation of the pleural drain was less when compared to intercostal insertion.

PICK et al. [22] demonstrated that this pain caused by intercostal drainage is capable of increasing pulmonary dysfunction in the postoperative period, which we confirmed in our study. This greater drop in the pulmonary function observed by the insertion of the pleural drain in the intercostal space occurs because it causes more injury to the thorax, perforating the parietal pleura and the intercostal muscles [3,5].

JAKOB et al. [4] showed that the high sensitivity of the pleura and the friction produced during respiratory movement provoke suffering to the patient, by constant irritation of the intercostal and periosteo-nerves. On the other hand, the patient defends himself with the immobilization of the thorax and superficial respiratory movements, with deep breaths being restricted until removal of the drain.

As an end result, with the insertion of a drain between the intercostal spaces reductions in the functional residual capacity, FVC and FEV, are intensified [23]. These alterations, associated to a reduction in the pulmonary complacency, increase the respiratory work. In this case, so that less energy is spent, the flow volume is reduced, leading alveoli to progressive collapse, resulting in a shunt and consequent hypoxemia [20].

Studies have shown that the greater the reduction of the $\mathrm{FVC}$ and $\mathrm{FEV}_{1}$, the greater the possibility of the patient evolving respiratory complications. In this study, although it was not assessed, the intercostal group as it presented 
with a greater reduction of these spirometry parameters may have been subjected to a greater occurrence of postoperative complications [23,24]. A reduction of the pulmonary volumes can lead to an accumulation of secretion in the airways, with the possibility of greater obstruction of the air flow, perhaps disposing the patient to the occurrence of atelectasis and pneumonia $[19,24]$.

In respect to the pleural drain, it has been frequently argued that the intercostal position is more efficacious in the draining of postoperative sanguineous collections. In this study and discussion, the pleural drains of the patients, independent of their position, were removed on the $2^{\text {nd }}$ postoperative day and there was no necessity of additional thoracocentesis, thus the drains were efficacious. This result is justified by the correct positioning of the end of the subxiphoid curved drain in the left costophrenic sinus $[4,13,21]$, as was demonstrated by postoperative thoracic radiography.

Patients in this study, with the drain positioned in the subxiphoid region were more tolerant, accepting the spirometry measurements better, in relation to those with the intercostal drain. A similar result was reported by SOFIA \& ALMEIDA [25], whose patients with the drain in the subxiphoid position presented with a greater tolerance and disposition for physiotherapeutic work.

As has been previously mentioned, due to the drop in the pulmonary function in the postoperative period of $\mathrm{CABG}$ surgery, the patient is vulnerable to pulmonary complications in this period of recovery.

Studies show that physiotherapy from the preoperative to the postoperative period is capable of maintaining good pulmonary conditions, reducing repercussions of injury of the pulmonary function. This is our opinion also, based on, not only the results of this study, but on experience with patients submitted to CABG surgery, independent of the site of the pleural drain. This study demonstrated that those patients using the intercostal site of the drain require special care as complications may occur more frequently due to the greater degree of compromise to the pulmonary function.

To avoid sectioning the intercostal spaces when inserting the pleural drain would be the best conduct. Using the subxiphoid access, avoiding the intercostal spaces, lessening the pain, avoiding greater injury to the pulmonary function and to the patient would be the best condition to cooperate with the important role of the physiotherapist in the postoperative period.

\section{CONCLUSION}

In conclusion, this study demonstrated that in off-pump CABG surgery using LITA grafts and left pleurotomy, independent of the position of the pleural drain, there is pain and damage of the pulmonary function. However, insertion of the drain in the subxiphoid region demonstrated a better preservation of the pulmonary function and less subjective pain when compared to the intercostal site.

\section{BIBLIOGRAPHIC REFERENCES}

1. Cameron A, Davis KB, Green G, Schaff HV. Coronary bypass surgery with internal thoracic artery grafts. Effects on survival over a 15-year period. N Engl J Med 1996;334:216-9.

2. Berrizbeitia LD, Tessler S, Jacobowitz IJ, Kaplan P, Budzilowicz $\mathrm{L}$, Cunningham JN. Effect of sternotomy and coronary bypass surgery on postoperative pulmonary mechanics. Chest 1989;96:873-76.

3. Peng MJ, Vargas FS, Cukier A, Filho MT, Teixeira LR, Light RW. Postoperative pleural changes after coronary revascularization. Chest 1992;101:327-30.

4. Jakob H, Kamler M, Hagl S. Doubly angled pleural drain circumventing the transcostal route relieves pain after cardiac surgery. Thorac Cardiovasc Surg 1997;45:263-4.

5. Lancey RA, Gaca C, Salm TJV. The use of smaller, more flexible chest drains following open heart surgery. Chest 2001;119:19-24.

6. WHO Physical Status: the use and interpretation of anthropometry. Report of a WHO Expert Committee. Geneve, World Health Organization, 1995;854:368-9.

7. Lipschitz DA. Screening for nutritional status in the elderly. Nutritional in old age. Am J Clin Nutr 1994;21:55-67.

8. American Thoracic Society. Standardization of spirometry. 1994 Update. Am J Respir Crit Care Med 1995; 1107-36.

9. Symreng T, Gomes MN, Rossi N. Intrapleural bupivacaine versus saline after thoracotomy on pain and lung function: a double-blind study. J Cardiothorac Anesth 1989;3:144-9.

10. Dureuil B, Cantineau JP, Desmonts. Effects of upper or lower abdominal surgery on diaphragmatic function. Br J Anesth 1987;59:1230-5.

11. Vargas FS, Cukier A, Filho MT, Hueb W, Teixeira LR, Light RW. Relationship between pleural changes after myocardial revascularization and pulmonary mechanics. Chest 1992;102:1333-6.

12. Calvin SH, Wan S Yim APC, Arifi AA. Pulmonary dysfunction after cardiac surgery. Chest 2002;121:1269-77.

13. Hagl C, Harringer W, Gohrbandt, Haverich A. Site of pleural drain insertion and early postoperative pulmonary function following coronary internal mammary artery. Chest 1999;115:757-61. 
14. Oiokkonen M, Karjalainen K, Karara V, Kuosa R, Schavikin L. Comparison of incentive spirometry and intermittent positive pressure breathing after coronary artery bypass graft. Chest 1991;99:60-5.

15. Quadrelli SA, Montiel G, Roncoroni AJ, Raimondi A. Complicaciones respiratorias en el postoperatorio inmediato de la cirugia coronaria. Medicina (Buenos Aires) 1997;57:742-54.

16. Yamagishi T, Ishikawa S, Ohtaki A, Takahashi T, KoyanoT, Ohki $\mathrm{S}$ et al. Postoperative oxygenation following coronary artery bypass grafting. J Cardiovasc Surg 2000;41:221-5.

17. Quadrelli AS, Brandani LM. Alteraciones del intercambio gaseoso em post-operatorio de cirugia cardíaca. Medicina (Buenos Aires) 1995;55:300-6.

18. Singh PN, Vargas FS, Cukier A, Filho MT, Teixeira LR, Light RW. Arterial blood gases after coronary artery bypass surgery. Chest 1992;102:1337-41.

19. Ali J, Weisel R, Layung A, Kripke B, Hechtman H. Consequences of postoperative alterations in respiratory mechanics. Am J Surg 1974;128:376-82.
20. Fernandes CR, Neto PPR. O sistema respiratório e o idoso: implicações anestésicas. Rev Bras Anestesiol 2002;52:461-9.

21. Riebman JB, Yurvati AHO, Laub GW. Improved technique for pleural drain insertion in cardiovascular surgery. J Cardiovasc Surg 1994;35:503-5.

22. Pick A, Dearani J, Odell J. Effect of sternotomy direction on the incidence of inadvertent pleurotomy. J Cardiovasc Surg 1998;39:673-6.

23. Greinecker GW, Hakimi MY, Rinne T, Buhl R, Matheis G, Martens $\mathrm{S}$ et al. Effect of internal thoracic artery preparation on blood loss, lung function, and pain. Ann Thorac Surg 1999;67:1078-82.

24. Craig DB. Postoperative recovery of pulmonary function. Anesth Analg 1981;60:46-52

25. Sofia RR, Almeida LG. Complicações pulmonares no pósoperatório de cirurgia cardíaca. In: Regenga MM (ed). Fisioterapia em cardiologia da UTI à reabilitação. $1^{\circ}$ ed. São Paulo:Roca; 2000. p. 31-43. 